\title{
PENGUATAN KEPEDULIAN MASYARAKAT TENTANG COVID-19 PADA MASA PANDEMI DI TIPES SERENGAN SURAKARTA
}

\author{
Kunti Dewi Kriswindayasti ${ }^{1}$, Catur Sugiarto ${ }^{2}$, Herman Saputro ${ }^{3}$, Syamsul Hadi ${ }^{4}$ \\ ${ }^{1}$ Ilmu Komunikasi Fakultas Ilmu Sosial dan Ilmu Politik Universitas Sebelas Maret \\ ${ }^{2}$ Ilmu Komunikasi Fakultas Ekonomi dan Bisnis Universitas Sebelas Maret \\ ${ }^{3}$ Teknik Mesin Fakultas Keguruan dan Ilmu Pendidikan Universitas Sebelas Maret \\ ${ }^{4}$ Teknik Mesin Fakultas Teknik Universitas Sebelas Maret \\ syamsulhadi@ft.uns.ac.id
}

\begin{abstract}
Abstrak
Abstrak. Indonesia saat ini tengah mengalami pandemi virus Middle East Respiratory Syndrome-Corona Virus atau COVID-19. Gejala dari virus ini sendiri adalah batuk, demam disertai panas, sesak nafas, infeksi pneunomia, sakit di bagian perut hingga menurunnya nafsu makan. Banyak kota di Indonesia terkena dampaknya mulai dari bidang ekonomi, pendidikan, kesehatan, sektor produksi dan juga aktifitas masyarakat yang terhambat akibat adanya virus ini. Salah satu daerah yang terdampak virus COVID-19 adalah di Kota Surakarta, tepatnya di daerah Puspan, Tipes, Serengan. Kegiatan Kuliah Kerja Nyata (KKN) Universitas Sebelas Maret, sebagai salah satu sarana pengabdian mayarakat, dengan mengambil Tema Covid19 berusaha berperan untuk meningkatkan kepedulian warga masyarakat terhadap pandemi tersebut. Konstribusi melalui tindakan aktif sangat perlu di masa pandemi guna mendukung pemahaman masyarakat. Kegiatan yang dilakukan berupa sosialisasi secara online guna peningkatan awareness masyarakat sekitar mengenai COVID-19. Kemudian penerapan pemahaman dan pendampingan mengenai Perilaku Hidup Bersih Sehat (PHBS).
\end{abstract}

Kata Kunci: KKN, COVID-19, PHBS, Pendampingan, Serengan, Surakarta

\section{PENDAHULUAN}

Indonesia saat ini tengah mengalami pandemi virus Middle East Respiratory SyndromeCorona Virus atau COVID-19. Virus ini merupakan salah satu penyakit infeksi saluran pernapasan yang berasal dari infeksi virus COVID-19. Virus ini sudah menginfeksi populasi dalam jumlah banyak dengan tingkat infeksi ringan hingga berat dan menyebabkan berbagai kasus kematian. Gejala dari virus ini sendiri adalah batuk, demam disertai panas, sesak nafas, infeksi pneunomia, sakit dibagian perut hingga menurunnya nafsu makan. Bahkan hingga tanggal 30 Juni 2020 terhitung angka positif COVID-19 di Indonesia mencapai 56.385 jiwa dengan angka kesembuhan mencapai 24.806 jiwa dan angka kematian mencapai 2.876 jiwa. (covid19.go.id)

Beberapa kota di Indonesia pun terkena dampaknya mulai dari bidang ekonomi, pendidikan, kesehatan, sektor produksi dan juga aktifitas masyarakat yang terhambat akibat adanya virus ini. 
Salah satu daerah yang terdampak virus COVID-19 adalah di Kota Surakarta, tepatnya di daerah Puspan, RT/RW 05, Tipes, Serengan. Keadaan di Kampung Puspan saat ini tergolong cukup sepi karena sedikit masyarakat yang beraktifitas, akan tetapi karena keadaan jugalah yang mengakibatkan aktifitas tersebut terhambat. Banyaknya masyarakat usia lanjut yang tinggal ditempat ini juga mengakibatkan ketakutan tersendiri dengan adanya Virus COVID-19. Selain itu, disepanjang jalan juga tidak ditemukan adanya himbauan atau papan informasi mengenai COVID-19 sehingga masyarakat di sana cenderung acuh dengan adanya wabah ini, dan tidak sedikit pula yang memberikan respon ketakutan berlebihan. Padahal, informasi mengenai COVID-19 seharusnya dapat diakses oleh seluruh masyarakat sehingga proses pemahaman serta pencegahannya dapat terjadi dengan efektif.

Pemerintah menetapkan tiga pilar kebijakan pendidikan melalui Undang-Undang Nomor 20 Tahun 2003 tentang Sistem Pendidikan Nasional (UUSPN2003), Peraturan Presiden No. 7 Tahun 2005 tentang Rencana Pembangunan Jangka Menengah (2005-2009) bidang pendidikan serta peraturan perundang undangan yang mendukungnya terutama dibidang pengabdian masyarakat (Idris dkk, 2010). Oleh karena itu, sebagai mahasiswa tentunya tidak boleh diam saja mengetahui keadaan tersebut. Konstribusi melalui tindakan aktif sangat perlu dimasa pandemi guna mendukung pemahaman masyarakat di Kampung Puspan, RT/RW 02/05 Tipes Surakarta. Tindakan ini nantinya dapat berupa sosialisasi secara online guna peningkatan awareness masyarakat sekitar mengenai COVID-19. Kemudian juga perlu diterapkan pemahaman dan pendampingan mengenai PHBS (Perilaku Hidup Bersih Sehat) (Husni dkk, 2015) dan perlunya penggalakan program social distancing agar dapat membantu pemerintah dalam memutus rantai penyebaran COVID-19 di Indonesia, juga menghilangkan stigma negatif yaitu ketakutan berlebihan dimasa pandemi agar imunitas juga tetap terjaga. Tidak terbatas hanya di Kampung Puspan saja, karena nantinya sosialisasi juga akan dilakukan dengan memanfaatkan media baru (social media) seperti youtube dan instagram (Agung dkk, 2017) agar persebaran informasi dapat diakses oleh lebih banyak target khalayak dan juga dapat bersamasama tanggap menghadapi Wabah COVID-19 dengan selalu menerapkan prinsip jaga jarak yang sesuai dengan SOP penanganan pandemi COVID.

\section{METODE}

Dari berbagai permasalahan yang ada di Puspan, Tipes, Serengan, dilakukan beberapa kegiatan periode KKN UNS Covid19 Batch 1 ini untuk mengurangi dampak permasalahan yang ada mulai dengan pemetaan data awal wilayah KKN dan pelaksanaan KKN dengan metode survey, sosialisai, pendampingan, kerja bersama, motivasi, penyuluhan dan monitoring. Metode yang dilakukan tersebut disesuaikan dengan masalah yang ada dan potensi yang ada di Puspan, Tipes, Serengan. Khalayak sasaran kegiatan PPM Prioritas ini adalah pemuda pemudi, aparat desa, kelompok tani, ibu-ibu PKK, anak anak, dan masyarakat sekitar Puspan, Tipes, Serengan. Mahasiswa melaksanakan berbagai tahapan kegiatan selama 40 hari dan tinggal bersama masyarakat sehingga menyelami kebutuhan riel masyarakat. Tahapan pelaksanaan KKN tersebut dapat diuraikan dalam satu tema besar tentang Pandemi Covid19 dan PSBB serta terdiri dari beberapa kegiatan yaitu Sosialisasi pembuatan masker sendiri (do it yourself atau DIY), pentingnya pemakaian masker, social distancing dan cuci tangan online melalui group chat dalam berbagai versi video, maupun poster. Serta melakukan pencetakan poster dan selebaran guna menambah informasi. Dan sosialisasi dengan pembuatan infografis tentang gizi-gizi makanan, dan contoh-contoh menu sehat guna menghadapi COVID-19. Pendampingan sosialisasi melalui video dengan RT/ RW juga kelompok masyarakat lainnya (Karang Taruna, organisasi lainnya) dan juga menyebarkan poster atau selebaran pentingnya social distancing; Pemberian alternatif kegiatan yang dapat dilakukan melalui video, pemberian tips and trick seputar stay at home, sosialisasi dengan Karang taruna setempat untuk dilakukan adanya teman bermain dan kegiatan lainnya yang dapat dilakukan dirumah saja; Updating kasus covid setiap harinya dan juga pemberian penjelasan kepada masyarakat tentang etika-etika yang harus dilakukan ketika sedang diluar (dalam kelompok sosial) misal etika batuk, etika menyapa seseorang, dll, serta Pembuatan konten-konten rutin dan pembuatan channel youtube khusus untuk sosialisasi mengenai COVID, PHBS dan update kasus setiap harinya yang diperuntukan khusus

Nama Sub tema Penelitian | 609 
untuk di share selama masa KKN guna mengedukasi masyarakat diluar RT/RW.

\section{HASIL DAN PEMBAHASAN}

Pada bidang kesehatan program kerja yang dilakukan adalah Supporting Pemahaman Masyarakat Mengenai COVID-19 dalam Bidang Kesehatan dengan PHBS (Perilaku Hidup Bersih Sehat)". Permasalahan yang ada yaitu minimnya informasi mengenai cara pencegahan COVID-19 dan partisipasi pemakaian masker, social distancing, cuci tangan di masyarakat Puspan Tipes; serta minimnya informasi mengenai gizi atau makanan sehat yang diperlukan untuk menjaga imunitas masyarakat setempat serta macam cara pencegahan covid.

Berdasarkan permasalahan yang ada maka dilakukan program kerja sosialisasi pembuatan masker sendiri (do it yourself atau DIY), pentingnya pemakaian masker, social distancing dan cuci tangan online melalui group chat dalam berbagai versi video, maupun poster. Serta melakukan pencetakan poster dan selebaran guna menambah informasi, dan sosialisasi dengan pembuatan infografis tentang gizi-gizi makanan dan contohcontoh menu sehat guna menghadapi COVID-19. Tujuan program kerja ini adalah untuk memberikan awareness masyarakat Puspan Tipes mengenai pentingnya penggunaan masker sebagai salah satu tindakan preventif dari pencegahan virus Corona, kemudian juga memberikan pemahaman mengenai pentingnya jaga jarak dikarenakan masih banyaknya masyarakat yang berkerumun dan bergerombol contohnya adalah di pos ronda, sehingga harus diberikan edukasi bahawa sangat penting untuk menjaga jarak dimasa pandemi. Kemudian yang terakhir adalah penerapan PHBS yaitu Perilaku Hidup Bersih dan Sehat dikarenakan masih minimnya tempat cuci tangan dan kebanyakan masyarakat tipes tidak mengetahui langkah-langkah cuci tangan yang benar sehingga perlu adanya edukasi secara langsung serta pembuatan tempat cuci tangan di berbagai spot keramaian di RT 02 RW 05 Tipes. Program kerja dalam bidang kesehatan dengan PHBS (Perilaku Hidup Bersih Sehat) sudah terlaksana dengan baik pada rentang waktu 35 hari.

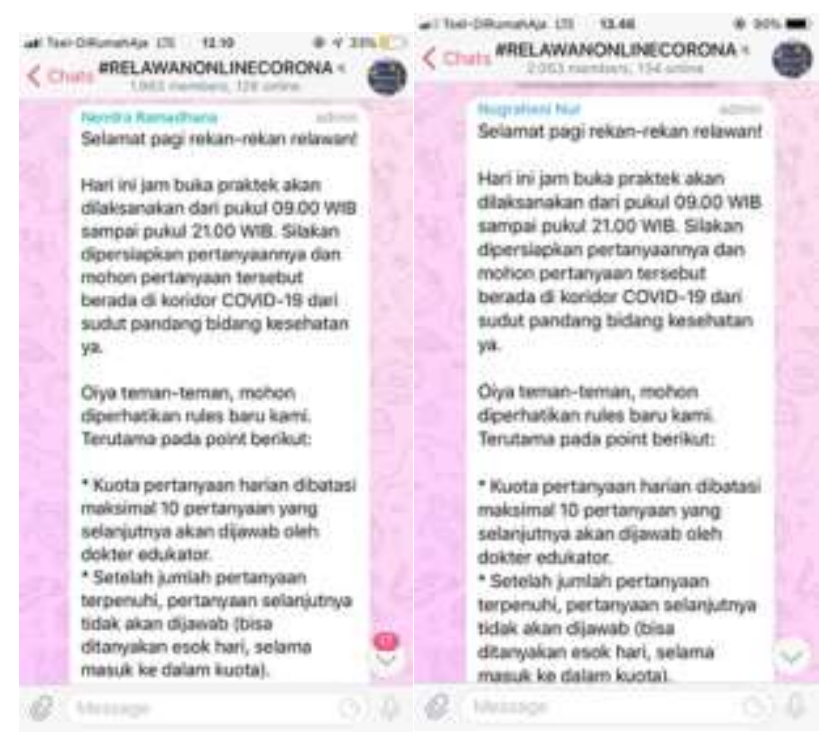

Gambar 1. Mengikuti diskusi tanya jawab relawan online corona via telegram

Pada bidang integrasi sosial dilakukan program kerja sosialisasi daring dan mini games guna menghilangkan kejenuhan saat masa karantina. Permasalahan yang ada selama ini adalah tidak maksimalnya gerakan social distancing dalam membantu pemerintah untuk pencegahan COVID19 dan adanya kejenuhan untuk tinggal di rumah (stay at home) karena tidak banyak variasi yang dapat dilakukan, serta minimnya informasi seputar perkembangan kasus COVID-19 dan apa yang harus dilakukan. Untuk itu program kerja yang dilakukan adalah pendampingan sosialisasi melalui video dengan RT/ RW juga kelompok masyarakat lainnya (Karang Taruna, organisasi lainnya) dan juga menyebarkan poster atau selebaran pentingnya social distancing, pemberian alternatif kegiatan yang dapat dilakukan melalui video, pemberian tips and trick seputar stay at home, sosialisasi dengan karang taruna setempat untuk dilakukan adanya teman bermain dan kegiatan lainnya yang dapat dilakukan dirumah saja; Updating kasus covid setiap harinya dan juga pemberian penjelasan kepada masyarakat tentang etika-etika yang harus dilakukan ketika sedang diluar (dalam kelompok sosial) misal etika batuk, etika menyapa seseorang, dll. Tujuan dilakukannya program ini adalah untuk menumbuhkan kesadaran masyarakat dan pengetahuan mendalam mengenai bahaya serta cara-cara penceghan COVID-19 yang dimulai dari unit terkecil organisasi masyarakat yaitu Karang

Lingkungan Hidup Dan Bencana | 610 
Taruna dan dengan pemberian konten-konten kreatif ini dari Karang Taruna dapat meneruskannya kemasyarakat sehingga banyak orang yang lebih peduli lagi dengan adanya Pandemi Corona, wawasannya juga bertambah lebih luas, selain itu mereka dapat menjadi anggota masyarakat yang selalu update mengenai perkembangan Corona. Kegiatan ini juga bertujuan agar masyarakat tidak bosan ketika diwajibkan karantina, serta dapat menerapkan etika-etika baru syang disesuaikan dengan adanya pandemi ini. Program Kerja dalam bidang Integritas Sosial dalam pelaksanaannya dinilai cukup sukses dikarenakan ada beberapa kegiatan yang dilakukan didalamnya yang menimbulkan feedback positif dari masyarakat. Kegiatan itu adalah:

1. Pembuatan Akun Youtube sebagai media edukasi penyebaran konten COVID-19

2. Pembuatan Grup WhatsApp dengan Karang Taruna untuk sosialisasi edukasi mengenai COVID-19 Secara Daring

3. Pembuatan Konten-Konten Video dan poster untuk sosialisasi yang kemudian disebarkan baik di sosial media pribadi, whatsapp grup, dan juga ditempelkan di lingkungan sekitar

4. Pembuatan proker sadar corona untuk anakanak RT 02 RW 05 Tipes dengan mengutamakan prinsip social distancing

5. Updating kasus corona di Indonesia setiap hari selama masa KKN di Whatsapp Grup, dan media sosial pribadi

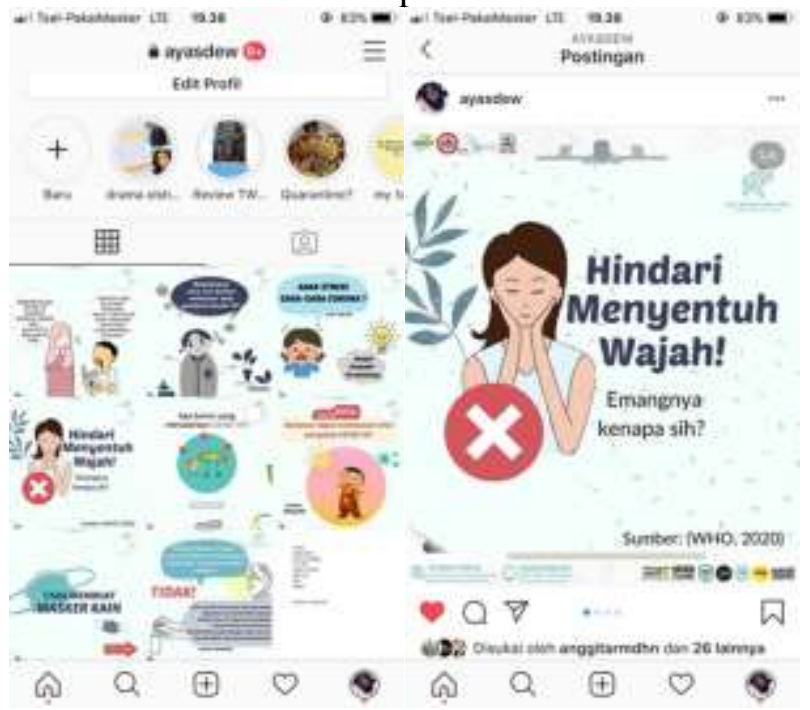

Gambar 2. Beberapa konten edukasi secara online untuk pencegahan penularan Covid-19

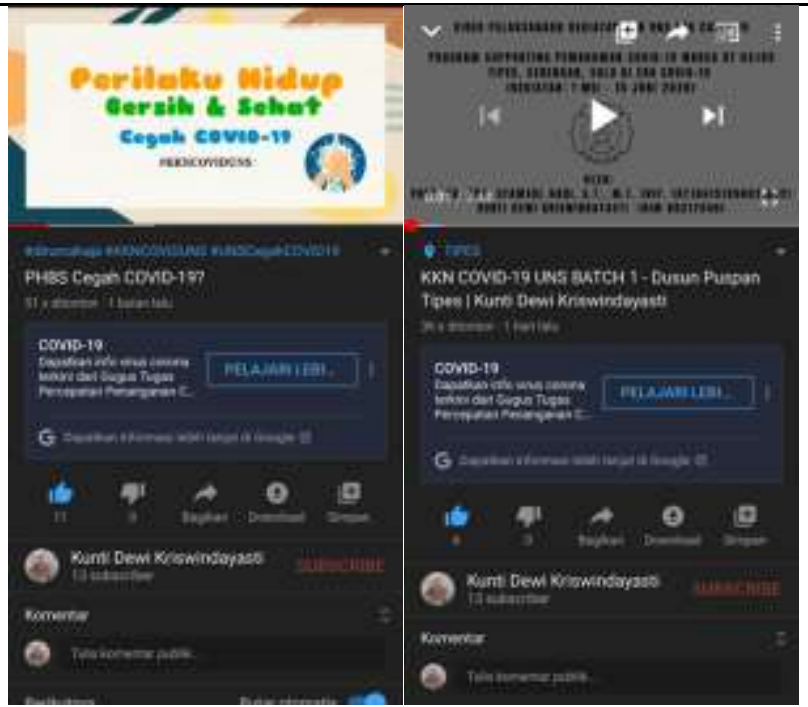

Gambar 3. Pembuatan konten YouTube

Kegiatan lain yang dilakukan adalah pemanfaatan media baru sebagai sarana kampanye awareness mengenai COVID-19 di masyarakat untuk menyikapi permasalahan banyaknya hoax yang tersebar saat masa pandemi yang mengakibatkan missleading tentang COVID. Program kerja yang dilakukan adalah pembuatan konten-konten rutin dan pembuatan channel youtube khusus untuk sosialisasi mengenai COVID, PHBS dan update kasus setiap harinya yang diperuntukan khusus untuk di share selama masa KKN guna mengedukasi masyarakat. Tujuan kegiatan ini adalah masyarakat jaman sekarang sudah mengalami perkembangan teknologi dengan adanya internet, oleh karena itu, internet sebagai media baru dimanfaatkan untuk pembuatan dan penyebaran konten-konten seputar COVID-19 agar awareness masyarakat modern mengenai COVID19 dapat diraih dalam program KKN UNS kali ini, dan konten-konten edukatif mengenai Corona juga dapat secara update diakses secara mudah didalam berbagai media sosial masyarakat luas. Hasil yang diperoleh adalah terbentuknya relawan online COVID-19. Relawan online COVID-19 ini memiliki jumlah anggota yang banyak dan juga memiliki berbagai program untuk edukasi secara online kepada masyarakat melalui konten-konten wajib yang di upload di media sosial pribadi. Dalam menjadi relawan online corona, hal-hal yang sudah dilakukan yaitu mengikuti diskusi aktif setiap hari di telegram mengenai qna atau tanya jawab seputar permasalahan corona dan juga edukasi mengenai berita-berita hoax seputar Corona langsung dengan 
para dokter dan tenaga medis yang terjun langsung dalam garda terdepan, sehingga sebagai relawan online saya dapat mneruskan informasi tersebut sebagai bahan sosialisasi dan menambah wawasan seputar covid-19

Selain diskusi online, program kerja relawan online Corona adalah penyebaran konten di media sosial pribadi (Instagram) mengenai informasi-informasi seputar covid-19 dan juga melawan hoax saat masa pandemi. Penyebaran konten tersebit telah saya lakukan selama satu minggu 1 hingga 2 kali sesuai dengan jadwal yang diberikan relawan online corona di instagram pribadi, guna meraih awareness dari masyarakat yang lebih luas (kerabat dan keluarga) sehingga dapat membantu kampanye yang dilakukan oleh relawan online Corona. Selama sebulan penuh, konten yang disebarkan melalui media sosial pun terbilang cukup efektif dikarenakan dapat meraih engagements yang baik di instagram dan impressi akun instagram pribadi @ayasdew terbukti naik pesat dan mendapatkan feedback yang positif dari followers dengan jumlah likes yang terbilang cukup bagus dengan kisaran 25-70 likes tiap postnya.

Program kerja berikutnya adalah pembuatan akun Youtube dengan menggunakan email student UNS. Pembuatan Youtube ini dikhususkan untuk sosialisasi secara daring mengenai pembahasan seputar COVID-19, sehingga sosialisasi yang dilakukan tidak terbatas hanya pada WhatsApp Grup Karang Taruna Tipes saja, namun sesuai tujuan bahwa media baru akan saya manfaatkan dengan lebih baik lagi untuk mencari target audiens yang lebih luas. Kemudian, konten-konten yang diupload di Youtube dalam pelaksanaannya video dibuat sendiri menggunakan aplikasi Adobe Premiere dan Kine Master sehingga dapat dijamin orisinalitasnya. Dalam pembuatan konten, sumber data diperoleh dari Kemenkes RI, WHO, serta berbagai artikel ilmiah maupun lepas yang disebarkan oleh relawan online Corona sehingga konten video yang dibuat terhindar dari hoax dan dapat dicek validitasnya. Untuk upload konten, dibagi menjadi 4 tema besar dan bedasarkan scheduling yang telah direncanakan sebelumnya yaitu setiap seminggu 1x dikarenakan harus melalui proses editing dan verifikasi konten. Konten yang diupload yaitu 1). Apa sih COVID-19?; 2). Pemahaman Pengenai PHBS; 3) Tips dan
Rekomendasi kegiatan saat \#stayathome; dan 4) kompilasi Video Pelaksanaan KKN COVID-19 Batch 1. Hasil yang cukup baik dari video dinunjukan dengan total 15 subscriber youtube dalam 1 bulan, jumlah rate likes dan komen feedback yang aktif, serta jumlah views yang mencapai puluhan dengan views range 20-100 views.

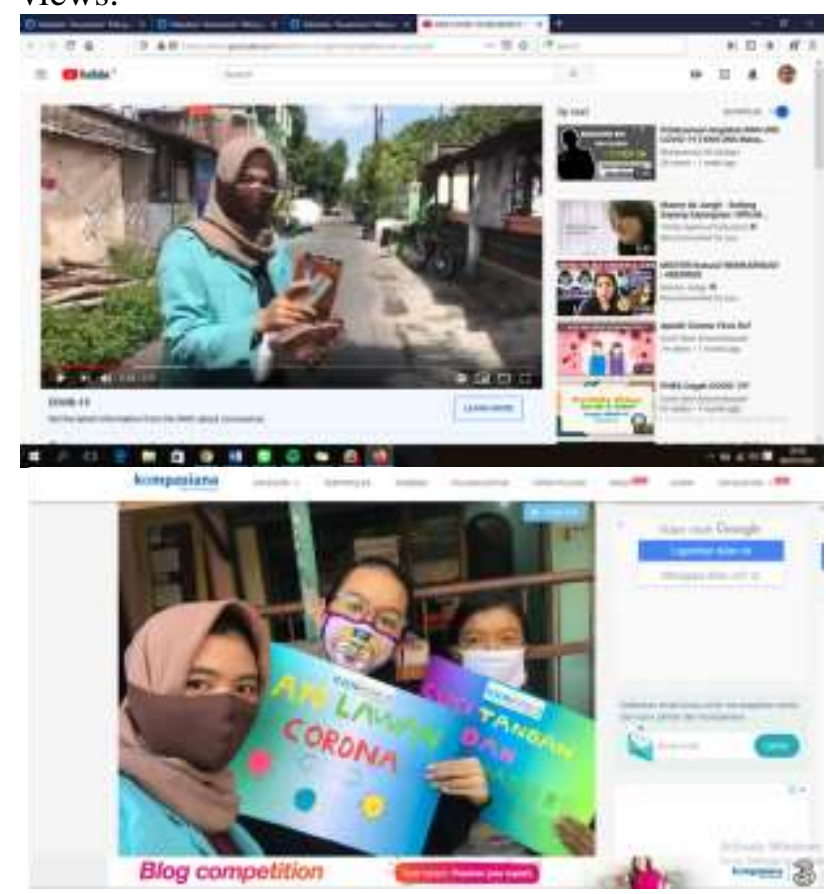

Hasil pengabdian masyarakat ini sudah disampaikan di salah satu media massa laporannya yaitu di https://www.kompasiana.com/kuntidewi 15f046aef097f360885719eb2/sebarkan-awarenessmengenai-covid-19-lewat-program-kuliah-kerja-nya ta-di-berbagai-daerah-indonesia-oleh-universitas-se belas-maret serta di sosilaisasikan melalui kanal video berikut https://youtu.be/mulghtmvphg.

\section{KESIMPULAN}

Program Kegiatan KKN UNS COVID-19 telah dilaksanakan yang terbagi dalam tiga bidang program kerja yaitu kesehatan, integritas sosial, dan media baru dan mampu membantu masyarakat dalam hal peningkatan kesadaran dan pemahaman terkait COVID-19 secara terkhusus bagi Tipes, Serengan, Surakarta dan juga masyarakat luas pada umumnya. Dengan adanya pemahaman dan kesadaran masyarakat diharapkan mampu mencegah terjadinya penambahan kasus COVID-19 di Kota Surakarta, juga masyarakat juga tidak Lingkungan Hidup Dan Bencana 612 
dengan mudah dapat termakan berita hoax. Selain itu, dengan adanya edukasi mengenai PHBS akan sangat membantu masyarakat Tipes dalam menerapkan selalu hidup sehat dalam lingkungannya, dan juga menambah wawasan baru mengenai COVID-19. Kegiatan KKN COVID-19 ini juga dinilai bermanfaat bagi mahasiswa sehingga dapat bersosialisasi dengan lingkungan masyarakat di daerah masing-masing dengan edukasi dan sosialisasi yang mendidik.

Saran untuk KKN Batch selanjutnya adalah persiapan yang lebih matang untuk program kedepannya seperti pemberian pembekalan materi yang lebih matang, mengurangi adanya misscommunication antar Mahasiswa, DPL, dan juga UP KKN, lebih lanjut mengenai alur kegiatan atau jadwal kegiatan pasti, pemberian dana diawal kegiatan sehingga kegiatan dapat segera dilaksanakan dan kebijakan yang tidak menyulitkan mahasiswa. Saran bagi masyarakat yang telah mengikuti adalah untuk tetap melanjutkan kegiatan yang telah diberikan dan bukan semata-mata dengan berhentinya kegiatan ini maka masyarakat tidak menerapkan apa yang telah diberikan selama masa KKN COVID-19 agar tujuan dari kegiatan ini dapat tercapai.

\section{UCAPAN TERIMAKASIH}

Kegiatan pengabdian pada masyarakat ini merupakan program KKN UNS yang dibiayai dengan dana PNBP UNS tahun 2020.

\section{REFERENSI}

Pemanfaatan Ilmu Pengetahuan Dan Teknologi Dalam Kegiatan Pengabdian Masyarakat Di Perguruan Tinggi, Jurnal Pendidikan Dan Kebudayaan. Vol. 16, No 3, Hal. 284 (2010)

Perilaku Hidup Bersih Dan Sehat (PHBS) Pada Tatanan Rumah Tangga Masyarakat Using, Jurnal IKESMA Vol. 11, No 1, Hal. 28 (2015)

Media Sosial Instagram Sebagai Sarana Sosialisasi Kebijakan Penyiaran Digital, Jurnal ASPIKOM, Vol. 3 Nomor 2, Hal. 257 (2017)

Https://Covid19.Go.Id/

Https://Www.Balitbangham.Go.Id/ 